\title{
Hypothyroidism as a Late Sequela in Patients with Graves' Disease Treated with Antithyroid Agents
}

\author{
LAWRENCE C. WOOD and SIDNEY H. INGBAR, Thorndike Laboratory of Harvard \\ Medical School and Department of Medicine, Beth Israel Hospital, Boston, \\ Massachusetts 02215; Thyroid Unit, Massachusetts General Hospital, Boston, \\ Massachusetts 02114
}

\begin{abstract}
A в S T R A C T In 1971, thyroid function was evaluated in 15 unselected patients whose only therapy for diffuse toxic goiter was a course of thionamide drug treatment completed 20-27 yr earlier. One patient was frankly hypothyroid by clinical and laboratory criteria. The remaining 14 patients appeared clinically euthyroid and had a normal serum thyroxine $\left(\mathrm{T}_{4}\right)$ concentration and thyroid radioiodine uptake (RAIU). Nevertheless, only 6 of 14 appeared to be entirely normal according to more refined criteria. The serum thyrotropin (TSH) concentration was markedly elevated in one patient and above the normal range $(1.6 \pm 2.0$; mean $\pm 2 \mathrm{SD})$ in five others. Thyroid stimulation with exogenous TSH revealed subnormal responses of the serum $\mathrm{T}_{4} \mathrm{I}$, RAIU, or both, in 7 of 11 patients tested. An abnormal iodideperchlorate discharge test was found in 5 of 10 patients and appeared most abnormal in patients with abnormal RAIU responses to TSH. Fluorescent antimicrosomal antibody was found in the serum of 12 of the 15 patients, in contrast to an expected frequency of $7 \%$ in normal individuals of the same age.
\end{abstract}

By the time a second major follow-up study was completed in 1978, two additional patients had become frankly hypothyroid. A third subject met accepted criteria for subclinical hypothyroidism. One of these subjects had had a clearly elevated serum TSH concentration in 1972, and the remaining two had exhibited the highest responses of serum TSH $(36,26 \mu \mathrm{U} / \mathrm{ml})$ to thyrotropin-releasing hormone among 10 patients tested in 1972.

One patient developed recurrent thyrotoxicosis in $1978,25 \mathrm{yr}$ after the onset of his first and only other apparent episode of hyperthyroidism. This patient was the only one who demonstrated a subnormal response to

A portion of this work was presented at the Annual Meeting of the American Thyroid Association, Chicago, Ill., 22 September 1972.

Received for publication 25 April 1979 and in revised form 9 July 1979. thyrotropin-releasing hormone in 1972 . The remaining nine subjects that could be studied in 1978 exhibited varying combinations of abnormalities of thyroid function.

It is concluded that progressive failure of thyroid function is a common occurence in long-standing Graves' disease, and it is suggested that this results from concomitant chronic thyroiditis. We postulate that this inherent tendency toward thyroid failure is exaggerated by surgery or radioactive iodine, explaining the progressive increase in, and inordinate frequency of, hypothyroidism after ablative modes of therapy in diffuse toxic goiter.

\section{INTRODUCTION}

Little is known of the natural course of the diffuse toxic goiter of Graves' disease in the absence of therapeutic intervention of one type or another, although such information would likely contribute to an elucidation of the pathogenesis of the disease and to an understanding of its response to alternate modes of therapy. Early considerations of this topic refer to the occurrence of remissions and exacerbations, and to the occasional development of hypothyroidism (1-3). However, these reports are largely anecdotal, are devoid of statistical analysis, and are undocumented by what would currently be considered to be acceptable laboratory criteria. Unfortunately, little if anything can be learned of the natural history of the disorder from a consideration of the course of patients who have received ablative therapy, i.e., surgery or radioactive iodine, since such treatment is predicated upon the ability of these destructive measures to alter the natural course of the disease over long periods of time or permanently.

These studies constitute a long-term follow-up of 15 patients with diffuse toxic goiter who, many years earlier, had received a course of treatment with thionamide drugs, long-since discontinued. Because there is no evidence in man that a period of treatment with the 
thionamides has any effect on thyroid structure or function that persists after treatment is withdrawn, the studies were predicated on the hypothesis that the long-term course of such patients would reflect with reasonable accuracy the natural course of the disease itself. In previous studies of the outcome of antithyroid therapy, maximum duration of follow-up has been $\cong 20$ yr (4), but more commonly has been in the range of 5-10 yr (5-13). Moreover, in these series, evaluation of thyroid status has been based on clinical appearance and measurements of serum protein-bound iodine or thyroxine $\left(\mathrm{T}_{4}\right)^{1}$ concentration, thyroid ${ }^{131} \mathrm{I}$ uptake, or a combination thereof. Generally, newer, more sensitive tests of the state of thyroid function have not been applied.

The only criterion for selection of the 15 patients described in this report was a history of diffuse toxic goiter treated with a thionamide drug from 20 to $27 \mathrm{yr}$ before the present follow-up was begun in 1971. No treatment for the thyroid had been administered in the interim, and, when the patients were first contacted in 1971 , they were engaged in their usual daily activities. They were considered to be euthyroid when reported in 1966 as part of a larger follow-up group (4). Of the 15 patients whom we saw in 1971, 1 was frankly hypothyroid; the others were clinically euthyroid, but many of them displayed laboratory evidence of thyroid malfunction, suggestive of mild thyroid failure. Consequently, we decided to extend the period of follow-up, adding additional testing procedures as they became available to ascertain both whether the abnormalities seen would be transient, permanent, or progressive and whether additional patients would become frankly hypothyroid. This report describes the findings obtained in both the initial follow-up study carried out in 1971 and the second follow-up study performed $7 \mathrm{yr}$ later. The data indicate, we believe, that impaired thyroid function is a frequent occurrence in patients with diffuse toxic goiter successfully treated with antithyroid drugs many years earlier. This may represent a gradual progression toward hypothyroidism that is a part of the natural course of Graves' disease.

\section{METHODS}

Records of patients with Graves' disease who had been treated only with antithyroid drugs at the New England Medical Center, Boston, Mass. were reviewed through the kind cooperation of Dr. Edwin B. Astwood and Dr. Carl E. Cassidy. Among the patients in their files, 17 were identified who had been treated before 1950 with a single course of antithyroid therapy for what was clearly diffuse toxic goiter, with or without ophthalmopathy. All were asked to return for follow-up and 15 responded, comprising of 11 women and 4 men whose ages

${ }^{1}$ Abbreviations used in this paper: $\mathrm{T}_{3}$, triiodothyronine; $\mathrm{T}_{4}$, thyroxine; TRH, TSH-releasing hormone; TSH, thyrotropin; RAIU, thyroid radioiodine uptake. at that time averaged $61 \mathrm{yr}$. One woman was only $29 \mathrm{yr}$ old; the ages of the others ranged between 50 and $72 \mathrm{yr}$ (Table I). All denied having received therapy for any thyroid disorder since their initial period of treatment and all considered themselves to be in good health. All 15 patients agreed to undergo an initial clinical evaluation and, to a greater or lesser extent, the laboratory tests described herein.

Initial follow-up studies (1971). After a complete history had been taken and a physical examination performed, a control blood sample was obtained and the serum promptly stored frozen for later measurements of basal serum $\mathrm{T}_{4}$, triiodothyronine $\left(\mathrm{T}_{3}\right)$, and thyrotropin (TSH) concentrations, as well as antithyroid antibodies. Measurements of the thyroid radioiodine uptake (RAIU) and the thyroid response to exogenous TSH were possible in 12 patients. Each was given a $7.5-\mu \mathrm{Ci}$ dose of ${ }^{131}$ I orally and the RAIU was measured $24 \mathrm{~h}$ later by a standard technique. $30 \mathrm{~h}$ after the initial dose of ${ }^{131} \mathrm{I}$, each patient was given $10 \mathrm{IU}$ of bovine TSH i.m. ${ }^{2} 18 \mathrm{~h}$ later $(48 \mathrm{~h}$ after the initial dose of ${ }^{131} \mathrm{I}$ ), the residual radioactivity in the patient's thyroid gland was measured and a second dose of ${ }^{131} \mathrm{I}(22.5 \mu \mathrm{Ci})$ was given by mouth. Once again, the 24-h RAIU was measured, correction being made for residual radioactivity. Immediately after the 24 -h measurement, a second blood sample was obtained for measurement of serum $T_{4}$ concentration.

After an interval of not less than 3 mo, iodide-perchlorate discharge tests were carried out in 10 of the patients (15). $500 \mu \mathrm{g}$ of stable iodine as potassium iodide was given by mouth, together with a $7.5 \mu \mathrm{Ci}^{131} \mathrm{I}$ tracer. $3 \mathrm{~h}$ later, the patient was asked to void. Immediately thereafter, radioactivity in the thyroid area was corrected for extrathyroidal ${ }^{131}$ I by subtracting the radioactivity measured over the thigh. Potassium perchlorate $(1.0 \mathrm{~g})$ was then given by mouth. $1 \mathrm{~h}$ later, the patient was asked to void again, after which both neck and thigh counts were repeated. Results were calculated as the percentage of decrease in the corrected epithyroid counts that occurred between the 3rd and 4th $h$.

Serum $\mathrm{T}_{4}$ concentration was measured by a modification of the Murphy-Pattee procedure (16). Radioimmunoassay was employed for the measurement of serum $\mathrm{T}_{3}$ and TSH (17) concentrations. For these assays, all samples from each patient were measured concomitantly in duplicate or triplicate. Antithyroglobulin antibodies were measured by the tanned erythrocyte technique (18), and antimicrosomal antibody by a fluorescent technique, using unfixed thyroid tissue from a patient with Graves' disease as antigen (19). ${ }^{3}$

In 1971 , at the time of the initial follow-up examinations, TSH-releasing hormone (TRH) was not available to us for use in studying these patients. Approximately 1 yr later, when this was no longer the case, TRH tests were performed in the 10 patients who appeared euthyroid and who agreed to the procedure. Patients were given a single injection of $200 \mu \mathrm{g}$ of TRH i.v., samples of blood being drawn for measurement of serum TSH concentration before and $10,20,30,45,60,90$, and $120 \mathrm{~min}$ after TRH administration.

Subsequent follow-up studies. During the years after the first follow-up, most patients from the original group were seen

${ }^{2}$ Thyrotropar, Armour Pharmaceutical Co., Ill. All patients were given TSH bearing the same lot number, samples of which had been tested for biological activity in a modification of the McKenzie (14) bioassay method.

${ }^{3}$ Tanned erythrocyte antithyroglobulin antibody was measured by the Boston Medical Laboratory, Waltham, Mass. Fluorescent antimicrosomal antibody was measured by Dr. Anne Forbes, Massachusetts General Hospital, Boston, Mass. TSH concentrations were measured by Dr. Bruce Weintraub, Massachusetts General Hospital, Boston, Mass. 
TABLE I

Clinical and Laboratory Findings in 1971 in Patients with Diffuse Toxic Goiter in Remission More than 20 yr after Antithyroid Therapy

\begin{tabular}{|c|c|c|c|c|c|c|c|c|}
\hline Patient & Age & Sex & $\begin{array}{c}\text { Serum } \\
T_{4}\end{array}$ & $\begin{array}{c}\text { Serum } \\
T_{3}\end{array}$ & $\begin{array}{l}\text { Serum } \\
\text { TSH }\end{array}$ & RAIU & $\begin{array}{c}\text { Antithyroid } \\
\text { anti- } \\
\text { thyroglobulin* }\end{array}$ & $\begin{array}{c}\text { Antibody } \\
\text { anti- } \\
\text { microsomal* }\end{array}$ \\
\hline & $y r$ & & $\mu g / d l$ & $n g / d l$ & $\mu U / m l$ & $\%$ dose & & \\
\hline J.N. & 63 & $\mathbf{M}$ & 2.1 & 65 & 38.0 & 15 & $1 / 25,000$ & + \\
\hline E.M.t & 56 & $\mathbf{F}$ & 7.5 & 95 & 31.0 & 30 & negative & + \\
\hline S.B. $\$$ & 61 & $\mathbf{F}$ & 4.7 & 80 & 5.3 & 28 & negative & + \\
\hline G.T. & 66 & $\mathbf{M}$ & 5.0 & 120 & 3.8 & & $1 / 2,500$ & + \\
\hline K.B. & 70 & $\mathbf{F}$ & 9.2 & 65 & 2.6 & 39 & $1 / 25$ & + \\
\hline S.M. & 29 & $\mathbf{F}$ & 7.2 & 85 & 5.5 & 19 & $1 / 5$ & + \\
\hline O.C. & 50 & $\mathbf{F}$ & 8.4 & 340 & 4.9 & 45 & $1 / 5$ & + \\
\hline F.S. & 56 & $\mathbf{F}$ & 9.3 & 100 & 4.6 & 50 & $1 / 5$ & + \\
\hline E.P. & 65 & $\mathbf{F}$ & 6.1 & 85 & 3.2 & 39 & negative & - \\
\hline M.W. & 69 & $\mathrm{~F}$ & 7.5 & 85 & 2.7 & 29 & negative & + \\
\hline H.Z. & 56 & $\mathbf{F}$ & 7.8 & 120 & 2.2 & & $1 / 5$ & + \\
\hline D.T. & 69 & $\mathbf{M}$ & 4.1 & 85 & 1.6 & 44 & $1 / 2,500,000$ & + \\
\hline R.C. & 72 & $\mathbf{M}$ & 7.1 & 130 & 1.4 & 53 & $1 / 5$ & + \\
\hline N.W. & 72 & $\mathbf{F}$ & 8.6 & 120 & $<1.0$ & 25 & negative & - \\
\hline E.S. & 68 & $\mathbf{F}$ & 11.3 & 130 & $<1.0$ & & 1/5 & - \\
\hline Mean & 61 & & 7.4 & 120 & 5.9 & 32 & & \\
\hline (SD) & & & 2.0 & 70 & 8.0 & 14 & & \\
\hline Normal range & & & $4-11$ & $60-130$ & $<4.0$ & $15-45$ & $<1 / 2,500$ & \\
\hline
\end{tabular}

* Antithyroglobulin antibodies measured by a tanned erythrocyte agglutination technique (18); antimicrosomal antibodies measured by a fluorescent technique (19).

† Patient taking estrogenic hormone for menopause.

$\S$ Patient received Teridax (iopanoic acid) for cholecystography many years earlier.

by one of us (Dr. Wood) at periodic intervals, others being followed by their family physicians. One patient (J.N.) had been found to be hypothyroid when first seen. One patient (E.M.) became frankly hypothyroid in 1972, and another (S.B.) in 1976. One patient (D.T.) became hyperthyroid in 1974.

In 1978, a second major follow-up examination was attempted in the remaining 11 patients. Nine patients responded to a request to return and underwent clinical examination and measurement of basal serum $\mathrm{T}_{4}, \mathrm{~T}_{3}$ and $\mathrm{TSH}$ concentrations. Four patients whose basal serum TSH values were clearly elevated or marginal were tested a second time with TRH, according to the protocol described above.

During the interval between the first and second follow-up studies the methods employed in our laboratories for measuring serum $\mathrm{T}_{4}$ and $\mathrm{T}_{3}$ concentrations had been changed. Serum $T_{3}$ concentrations continued to be measured by radioimmunoassay, but the details of the procedure were different $(20)$, with a resulting change in the normal range. Serum $T_{4}$ measurements during the second study were also performed by radioimmunoassay (20), in contrast to the competitive proteinbinding method initially employed. Serum TSH measurements during the second study were performed in the same laboratory by the same method as had been used during the first study, with only minor modifications that did not alter the normal range (20).

\section{RESULTS}

Follow-up in 1971. At the time of the first follow-up study, J.N., then a 63-yr-old white male, was clinically hypothyroid, the history suggesting that he had been so for 3-5 yr. The diagnosis was confirmed by base-line values of serum $\mathrm{T}_{4}$ and $\mathrm{TSH}$ concentrations, which were subnormal $(2.1 \mu \mathrm{g} / \mathrm{dl})$ and abnormally high $(38 \mu \mathrm{U} / \mathrm{ml})$, respectively, although serum $T_{3}$ concentration $(65 \mu \mathrm{g} /$ dl) was normal for the method then employed (Table I). The response to exogenous TSH was abnormal in that serum $\mathrm{T}_{4}$ concentration failed to increase, and the 24 -h thyroid ${ }^{131}$ I uptake showed a subnormal increase, from 15 to $22 \%$ (Table II). After administration of replacement doses of desiccated thyroid, signs and symptoms of hypothyroidism abated, and the serum $\mathrm{T}_{4}$ and TSH concentrations both became normal $(7.7 \mu \mathrm{g} / \mathrm{dl}$ and 3.3 $\mu \mathrm{U} / \mathrm{ml}$, respectively).

The remaining 14 patients were euthyroid as judged from their history and physical examination. Values of the serum $\mathrm{T}_{4}$ concentration were normal $(7.4 \pm 2.0 \mu \mathrm{g} /$ $\mathrm{ml}$; mean $\pm \mathrm{SD}$ ), except in E.S., in whom the value of $11.3 \mu \mathrm{g} / \mathrm{dl}$ was slightly above the upper limit of the normal range (Table I). In all but one patient (O.C.), serum $T_{3}$ concentrations in the clinically euthyroid group ranged between 65 and $130 \mathrm{ng} / \mathrm{dl}$. The latter values were well within the normal range of the method then employed $(90 \pm 18 \mathrm{ng} / \mathrm{dl})$. The clearly elevated value of $340 \mathrm{ng} / \mathrm{dl}$ in patient O.C. is unexplained. 
TABLE II

Responses to TSH Stimulation and Iodide-Percholate Discharge Tests in 1971 in Patients with Treated Diffuse Toxic Goiter

\begin{tabular}{|c|c|c|c|}
\hline \multirow[b]{2}{*}{ Patient } & \multicolumn{2}{|c|}{ Response to TSH } & \multirow{2}{*}{$\begin{array}{c}\text { Iodide-percholate } \\
\text { discharge test } \\
\Delta \text { RAIU }\end{array}$} \\
\hline & $\Delta$ Serum $T_{4}$ & $\Delta$ 24-h RAIU* & \\
\hline & $\mu g / d l$ & \%initial value & $\%$ change \\
\hline J.N. & +0.2 & +47 & \\
\hline E.M. & -1.5 & -37 & -78 \\
\hline S.B. & +2.7 & +36 & \\
\hline G.T. & & & -14 \\
\hline K.B. & +1.9 & -18 & -38 \\
\hline S.M. & +4.2 & -47 & \\
\hline O.C. & +2.0 & +82 & \\
\hline F.S. & +3.5 & +44 & +1 \\
\hline E.P. & +4.0 & +115 & -8 \\
\hline M.W. & +4.0 & +127 & -20 \\
\hline H.Z. & & & -31 \\
\hline D.T. & +5.4 & +121 & -9 \\
\hline R.C. & +0.1 & -61 & -29 \\
\hline N.W. & +3.9 & +128 & -4 \\
\hline \multicolumn{4}{|l|}{ E.S. } \\
\hline Mean $\pm S D$ & $2.8 \pm 2.0$ & $44 \pm 75$ & $-23 \pm 23$ \\
\hline Normal response & $4.8 \pm 1.6 \ddagger$ & $>50 \S$ & $-5 \pm 5$ \\
\hline$($ mean $\pm S D)$ & $3.7 \pm 1.9^{\prime \prime}$ & & \\
\hline
\end{tabular}

* RAIU; $\left(\right.$ RAIU $_{2}-$ RAIU $\left._{1}\right) / \mathrm{RAIU}_{1} \times 100$.

$\$$ According to Jeffries et al. (28).

$\$$ According to Fletcher and Besford (27).

"According to Burke (29).

I [(4-h RAIU) - (3-h RAIU)/(3-h RAIU)] × 100 (15).

Values of the RAIU, measured in 11 of the 14 patients, ranged from 19 to $53 \%$ of the administered dose, averaging $32 \pm 14$. Values in two patients (F.S. and R.C.) were above the upper limit of the normal range at that time $(45 \%)$.

Among 14 patients who appeared clinically euthyroid when first seen, and who displayed normal values for serum $\mathrm{T}_{4}$ concentration and thyroid ${ }^{131}$ I uptake, one (E.M.) also demonstrated a markedly elevated serum TSH concentration $(31 \mu \mathrm{U} / \mathrm{ml})$ and grossly abnormal responses to both the exogenous TSH stimulation and the iodide-perchlorate discharge tests. In view of these abnormalities and the fact that she developed clinical hypothyroidism within the next $2 \mathrm{yr}$, her findings will be excluded from the analysis of the data obtained in 1971 in the remaining 13 patients seen.

Values of the serum TSH concentration in these 13 patients were examined individually and for the group as a whole. To make this assessment, values obtained in the patients in the study group were compared with those obtained in the same laboratory in two control groups. The first group comprised 51 normal adult men and women of different ages. Values in this group ranged up to $4.3 \mu \mathrm{U} / \mathrm{ml}$. Mean values and $95 \%$ confidence intervals were calculated on the basis of data indicating that the serum TSH concentration in normal individuals conforms to a log-normal distribution. ${ }^{4}$ When calculated on this basis, values in the control group averaged $1.6 \mu \mathrm{U} / \mathrm{ml}$ and the $95 \%$ confidence interval (mean $\pm 2 \mathrm{SD}$ ) was $0.6-4.6 \mu \mathrm{U} / \mathrm{ml}^{5}{ }^{5}$ Three patients among the residual group of 13 had values in excess of $4.6 \mu \mathrm{U} / \mathrm{ml}$.

Because the mean age of the 13 patients under consideration was $62 \mathrm{yr}$ in 1971, and because the serum TSH concentration is said to increase slightly with increasing age (21), measurements of serum TSH concentrations were made in 12 randomly selected men and women who ranged in age between 50 and $76 \mathrm{yr}$ (mean age, $60 \mathrm{yr}$ ) and lacked any evidence of thyroid disease. Values in this group ranged between undetectable $(<0.3-<0.6 \mu \mathrm{U} / \mathrm{ml}$ in three subjects $)$ and $2.8 \mu \mathrm{U} / \mathrm{ml}$.

Because of the uncertainties posed by the occurrence of some values below the limit of detectability in the age-matched control and study groups, nonparametric methods of statistical analysis were also applied. Chisquare analysis revealed highly significant differences between values for serum TSH concentration in the 13 residual patients with treated Graves' disease and those in either the group of age-matched controls $(P<0.01)$ or the larger group of controls $(P<0.001)$. In addition, when analyzed by the Wilcoxon rank test (22), values in the residual 13 patients with Graves' disease were significantly higher than in the age-matched controls $(P<0.05) .^{6}$

Among the residual 13 clinically euthyroid patients, TSH stimulation tests were conducted in 10 (Table II). Studies were not conducted in an age-matched control group in view of both ethical constraints posed by untoward cardiac complications (23-25) and the fact that the functional response to exogenous TSH stimulation is apparently unaltered by increasing age (26). In the group of 10 patients as a whole, the fractional thyroid ${ }^{131}$ I uptake increased by an average of $53 \%$, but responses were widely dispersed (SD, 75\%). In 5 of the 10 patients, the response of the RAIU exceeded the lower limit of the normal response, which for the mode of testing employed has been defined as an increase amounting to at least half of the original value (27). In the remaining five patients, responses were subnormal, and, in four of these, values of the 24-h RAIU after TSH

\footnotetext{
${ }^{4}$ Ingbar, S. H., L. E. Braverman, and B. I. Ransil. Unpublished observations.

${ }^{5}$ In these calculations, values below the limit of detectability of the assay were assigned a value equal to the lower limit of detectability in that particular assay.

${ }^{6}$ In performing this test, we considered all values below the limit of detectability of the assay to be equal to one another.
} 
stimulation were actually lower than control values. Because this result was unexpected, studies were repeated in two patients (E.M. and R.C.), with confirmation of the initial results.

Responses of the serum $\mathrm{T}_{4}$ concentration to exogenous TSH were more difficult to assess for several reasons. First, previous studies have examined the responses of the serum protein-bound iodine, rather than serum $T_{4}$, concentration. Second, normal responses of the PBI to TSH administration as reported in the literature have varied widely, one report indicating an increase in PBI of $3.1 \pm 1.1 \mu \mathrm{g} / \mathrm{dl}$ after only $5 \mathrm{IU}$ of TSH (28) and another an increase of $2.5 \pm 1.0 \mu \mathrm{g} / \mathrm{dl}$ after $10 \mathrm{IU}$ of TSH (29). Among the 10 tests conducted in the 13 residual patients in the present series, only one clearly subnormal response was evident, that in patient R.C., in whom the serum $\mathrm{T}_{4}$ after $10 \mathrm{IU}$ of TSH increased by only $0.5 \mu \mathrm{g} / \mathrm{dl}$ (equivalent to an increase in protein-bound iodine of $0.3 \mu \mathrm{g} / \mathrm{dl}$ ). For the entire group of 10 patients, a high degree of correlation was found between the magnitude of the responses of the RAIU and the serum $\mathrm{T}_{4}$ to TSH administration $(r=0.97$, $P<0.005$ ).

Iodide-perchlorate discharge tests were performed in 9 of the residual 13 patients (Table II). As the test is performed in our laboratory, the $95 \%$ confidence limit of the normal response ranges between a discharge of $15 \%$ of thyroid ${ }^{131}$ I and an increase of $5 \%$ (15). Abnormal responses, i.e., discharge of more than $15 \%$, were observed in four of the nine tests, responses for the entire group averaging $-17 \pm 13 \%$.

TRH tests were performed in 1972 in 10 of the 13 patients. Responses were compared with those obtained in the course of TRH tests carried out according to the same protocol in the entire control group of 51 euthyroid subjects whose basal TSH concentrations were described above. In this control group, peak values for the serum TSH concentration were seen at 20 or 30 min after TRH administration and ranged between 4.5 and $27 \mu \mathrm{U} / \mathrm{ml}$.

Among the 10 patients who were tested, the peak value of $36 \mu \mathrm{U} / \mathrm{ml}$ in one patient (S.B.) was well above the normal range and in two others was near the upper limit seen in the normal group $(24 \mu \mathrm{U} / \mathrm{ml}$ R.C. and 26 $\mu \mathrm{U} / \mathrm{ml}$ in G.T.). In one patient (D.T.), a subnormal response, with a peak serum TSH of only $2.8 \mu \mathrm{U} / \mathrm{ml}$, was observed. Responses to TRH in the remaining six patients were normal.

When the entire group of 15 patients with Graves' disease was studied in 1971, only 3 demonstrated abnormal titers of antithyroglobulin antibodies as judged from tanned erythrocyte agglutination tests. However, 12 of the $15(80 \%)$, demonstrated antimicrosomal antibodies by the indirect fluorescent technique. These results contrasted strikingly to those obtained in control studies carried out in the same laboratory at the same time. Among sera from 56 randomly selected individuals between the ages of 51 and $70 \mathrm{yr}$ who lacked evidence of thyroid disease, positive tests were found in only 1 of 24 males and 3 of 32 females.

Interval between 1971 and 1978. At the conclusion of the follow-up studies in 1971, there remained of the original 15 patients 14 who were clinically well. In 1972, E.M. developed clinical hypothyroidism, with a decrease in serum $\mathrm{T}_{4}$ concentration from 7.5 to 2.3 $\mu \mathrm{g} / \mathrm{dl}$ and an increase in serum TSH concentration to $>50 \mu \mathrm{U} / \mathrm{ml}$. This patient was 1 of the 14 who appeared clinically euthyroid in 1971 , but at that time among this group she displayed the most clearly abnormal basal serum TSH concentration, response to exogenous TSH stimulation, and iodide-perchlorate discharge test. After replacement therapy with levothyroxine was instituted in 1972, she became clinically normal and has remained so since.

In 1976, a third patient (S.B.), who was being followed by her private physician, developed clinical hypothyroidism, documented by a serum $\mathrm{T}_{4}$ concentration of $2.7 \mu \mathrm{g} / \mathrm{dl}$ and a serum TSH concentration $>50$ $\mu \mathrm{U} / \mathrm{ml}$. In 1971 , this patient had demonstrated a serum $\mathrm{T}_{4}$ concentration of $4.7 \mu \mathrm{g} / \mathrm{dl}$, a marginal response to exogenous $\mathrm{TSH}$, and a basal serum TSH concentration slightly above the normal range. During the TRH tests performed in 1972, she displayed the greatest peak response $(36 \mu \mathrm{U} / \mathrm{ml})$ among the 10 patients then tested. Since 1976, when replacement therapy was begun, she has remained clinically euthyroid.

One patient (D.T.) developed recurrent hypothyroidism. Thyroid function studies performed in 1971 were all within normal limits. In 1972, however, his serum TSH concentration in response to exogenous TRH rose to only $2.8 \mu \mathrm{U} / \mathrm{ml}$, the only subnormal response seen among those in the 10 patients tested. He remained clinically well, however, until 1976 when he developed clear symptoms of hyperthyroidism associated with a serum $T_{4}$ concentration of $16.0 \mu \mathrm{g} / \mathrm{dl}$. The patient was treated with radioactive iodine and has since been well.

Follow-up in 1978. By 1978, 4 patients from the original 15 had been eliminated from the study because they had developed overt thyroid malfunction. Two other patients could not be located. Hence, nine patients were potentially available for study. All nine underwent clinical evaluation and repeat measurements of basal serum $\mathrm{T}_{4}, \mathrm{~T}_{3}$, and TSH concentrations (Table III). All were clinically well.

Serum $\mathrm{T}_{4}$ concentrations ranged between 6.1 and $10.5 \mu \mathrm{g} / \mathrm{dl}$ and serum $\mathrm{T}_{3}$ concentrations between 91 and $180 \mu \mathrm{g} / \mathrm{dl}$. Basal serum TSH concentrations were clearly above the normal range in G.T. and K.B. (10.2 and $6.1 \mu \mathrm{U} / \mathrm{ml}$, respectively). TRH responses were assessed in these two patients and in two others (E.P. 
TABLE III

Comparison of Serum $T_{4}, T_{3}$, and TSH Concentrations and TSH Responses to TRH at Initial and Follow-up Evaluations

\begin{tabular}{|c|c|c|c|c|c|c|c|c|}
\hline \multirow[b]{2}{*}{ Patient } & \multicolumn{2}{|c|}{ Serum $T_{4}$} & \multicolumn{2}{|c|}{ Serum $T_{3}$} & \multicolumn{2}{|c|}{ Serum TSH } & \multicolumn{2}{|c|}{$\begin{array}{l}\text { Peak serum TSH } \\
\text { after TRH }\end{array}$} \\
\hline & 1971 & 1978 & 1971 & 1978 & 1971 & 1978 & 1972 & 1978 \\
\hline & \multicolumn{2}{|c|}{$\mu \mathrm{g} / d l$} & \multicolumn{2}{|c|}{ ng/dl } & \multicolumn{2}{|c|}{$\mu U / m l$} & & \\
\hline J.N. & 2.1 & - & 65 & - & 38.0 & - & - & - \\
\hline E.M. & 7.5 & $2.3^{*}$ & 95 & - & 31.0 & $>50^{*}$ & - & - \\
\hline S.B. & 4.7 & $2.7 \ddagger$ & 80 & - & 5.3 & $>50 \ddagger$ & 36 & - \\
\hline G.T. & 5.0 & 6.6 & 120 & 105 & 3.8 & 10.2 & 26 & $24^{\prime \prime}$ \\
\hline K.B. & 9.2 & 9.8 & 65 & 118 & 2.6 & 6.1 & 16 & 21 \\
\hline S.M. & 7.2 & 6.1 & 85 & 151 & 5.5 & 2.9 & - & - \\
\hline O.C. & 8.4 & 9.1 & 340 & 180 & 4.9 & 1.4 & 16 & - \\
\hline F.S. & 9.3 & 10.4 & 100 & 91 & 4.6 & 2.0 & 15 & - \\
\hline E.P. & 6.1 & 10.5 & 85 & 114 & 3.2 & 2.2 & 15 & 12 \\
\hline M.W. & 7.5 & 8.5 & 85 & 150 & 2.2 & 1.5 & 9.5 & - \\
\hline H.Z. & 7.8 & - & 120 & - & 2.0 & 3.7 & - & - \\
\hline D.T. & 4.1 & $16.0 \$$ & 85 & - & 1.6 & - & 2.8 & - \\
\hline R.C. & 7.1 & $9.4^{\circ}$ & 130 & 150 & 1.4 & 4.0 & 24 & 15 \\
\hline N.W. & 8.6 & 9.3 & 120 & 99 & $<1.0$ & 1.0 & 7.0 & - \\
\hline E.S. & 11.3 & - & 130 & - & $<1.0$ & - & - & - \\
\hline Mean & 7.4 & 8.9 & 120 & 128 & 3.6 & 2.79 & & \\
\hline (SD) & $(2.0)$ & 1.4 & (70) & 28.3 & 2.8 & $1.9 \pi$ & & \\
\hline Normal range & $4-11$ & $4-11$ & $60-130$ & $70-190$ & $<4.6$ & $<4.6$ & $4.5-27$ & $4.5-27$ \\
\hline
\end{tabular}

* Value obtained in 1972, when patient clinically hypothyroid. † Value obtained in 1976, when patient clinically hypothyroid.

$\$$ Value obtained in 1976 , when patient clinically hyperthyroid.

"Test done after 3 mo treatment with $\mathrm{T}_{4}, 0.025 \mu \mathrm{g} / \mathrm{d}$.

If Excludes patients E.M. and S.B., then clinically hypothyroid.

and R.C.) who agreed to the test. Responses of the serum TSH concentration were within normal limits in three (K.B., E.P., and R.C.). The fourth patient (G.T.), who had the basal serum TSH concentration of 10.2 $\mu \mathrm{U} / \mathrm{ml}$, had been receiving $25 \mu \mathrm{g}$ of levothyroxine daily for 3 mo before the TRH test could be performed. Despite this, a response at the upper limit of the normal range was obtained, the peak value of the serum TSH concentration reaching $24.0 \mu \mathrm{U} / \mathrm{ml}$ at $30 \mathrm{~min}$.

\section{DISCUSSION}

It is entirely evident that some degree of thyroid failure is commonly the late outcome in patients with the diffuse toxic goiter of Graves' disease who have been treated by ablative means, i.e., radioiodine or surgery. The major conclusion of this study is that this is also the case, though to a lesser extent and after a longer interval, in patients who have been treated with antithyroid drugs. This conclusion is based on studies in 15 patients selected only to the extent that they conformed to the following criteria: an unequivocal diagnosis of Graves' disease at the time they were thyrotoxic; treatment only with an antithyroid agent at least $20 \mathrm{yr}$ earlier; persistence of an apparently euthyroid state after treatment was withdrawn; and absence of any additional treatment for thyroid disease since that time. Among these 15 patients, 1 (J.M.) was clinically hypothyroid when first seen, 2 others (E.M. and S.B.) developed frank hypothyroidism later, and subclinical hypothyroidism is now present in at least a 4th (G.T.).

It appears of interest to examine the various indices of thyroid function obtained in 1971-1972 among the 14 patients who were clinically euthyroid at that time in an effort to ascertain the ability of these indices to predict the patient's subsequent course. Serum $T_{4}$ and, with one exception, $T_{3}$ concentrations were within the normal range in all and bore no relationship to the later outcome. The same is true of the 24-h RAIU. The response to exogenous TSH was grossly abnormal in E.M., whose TSH was clearly elevated and who developed frank hypothyroidism, but was also abnormal in several others, especially R.C., who have not developed progressive thyroid failure to this time. The iodide-perchlorate discharge test correlated excel- 
lently with the response of the RAIU to exogenous TSH and was most abnormal in E.M., but failed to correlate in general with the subsequent clinical course. Similarly, antithyroglobulin antibodies showed no correlation with clinical course, and antimicrosomal antibodies were present in all but three patients, none of whom have shown evidence of progressive thyroid failure.

Clearly, among the tests performed in 1971 and 1972, those that have borne the closest correlation to the status of thyroid function 6-7 yr later are those that relate to the activity of the TSH secretory mechanism. A marked elevation of basal TSH concentration was present in 1971 in E.M., who developed overt hypothyroidism within $2 \mathrm{yr}$. None of the remaining basal TSH values were clearly elevated in 1971, although some appeared to be at or slightly above the upper limit of the normal range and values for the group as a whole were significantly higher than normal. When TRH tests were performed in 1972, the highest response was found in S.B., who became hypothyroid in 1976, and the next highest was found in G.T., the patient who now appears to have subclinical hypothyroidism. A rather brisk response to TRH was also evident in 1972 in R.C., but he continues to be euthyroid by all criteria presently available.

Further to this point, it is of particular interest to note that the response to TRH in 1972 was subnormal in D.T. who, in 1974 , more than $25 \mathrm{yr}$ after his initial episode, developed recurrent thyrotoxicosis.

Because all but one of the patients are now more than $60 \mathrm{yr}$ of age, the question must be raised as to whether the thyroid failure that we have observed is related to the age of the patients, rather than their Graves' disease. This seems clearly not to be the case, because frank hypothyroidism was seen in 3 of 14, a frequency far greater than the $\cong 3 \%$ frequency reported to be present in an unselected population of individuals admitted to a geriatric rehabilitation unit (30). Moreover, the very brisk response to TRH seen in 1978 in a fourth patient (G.T.), who is thought to have subclinical hypothyroidism, occurred despite the fact that he had been receiving $25 \mu \mathrm{g}$ of levothyroxine daily and in the face of evidence that the response to TRH declines with age in the male (31).

There is no reason to believe that the impairment of thyroid function that these patients displayed could have resulted from the antithyroid therapy they had received many years before. We would conclude, instead, that it is a consequence of Graves' disease per se or some concomitant thereof. We believe that the most likely causative factor is concomitant chronic thyroiditis. Direct support for this suggestion is provided by the finding of antimicrosomal antibodies in $80 \%$ of the patients in this series, but in only $7 \%$ of an age-matched control group studied in the same labora- tory by the same technique. Indirect evidence supporting the suggestion is to be found in the frequency with which histological evidence of chronic thyroiditis is found in diffuse toxic goiters, as well as in the presumed autoimmune origin of both Graves' disease and Hashimoto's disease, as evidence by high serum titers of antimicrosomal antibodies in both and in their concurrence in members of the same family or in the same patient, often in association with other disorders of presumed autoimmune origin (32).

The one unavoidable selection factor in these studies stemmed from the need to study patients who had not been treated with surgery or radioactive iodine, i.e., who had been successfully treated with antithyroid drugs alone. It might be argued, therefore, that patients who experience remission after a course of antithyroid therapy represent a special class of patients with diffuse toxic goiter, one that is particularly prone to develop delayed hypothyroidism. It is unlikely, however, that this caveat can ever be evaluated because patients who do not respond favorably to antithyroid therapy (as well as many who might) are generally subjected to ablative forms of treatment.

It is our belief that the tendency toward thyroid failure is not unique to a subclass of patients with Graves' disease, but rather reflects a long-term trend within the disease as a whole, resulting in all likelihood from associated chronic thyroiditis. In this light, it is not surprising, in our view, that hypothyroidism becomes manifest continuously over the years in patients with Graves' disease who have been treated for hyperthyroidism with surgery, or perhaps radioiodine $(33$, 34). Ablative treatment, by decreasing functioning thyroid mass, would then unmask and accelerate an intrinsic trend toward ultimate thyroid failure. Support for this suggestion is found in the numerous studies that have shown a positive correlation between, on the one hand, the frequency of development of postoperative hypothyroidism in patients with Graves' disease and, on the other hand, the severity of histologic evidence of autoimmune thyroid disease in resected specimens, the titer of circulating antithyroid antibodies, or both $(35,36)$. Be that as it may, the present findings indicate clearly, as initially concluded in 1888 (36), that patients with diffuse toxic goiter require life-long observation.

\section{ACKNOWLEDGMENTS}

This work was supported in part by grant AM-18416 from the National Institute of Arthritis, Metabolism, and Digestive Diseases, National Institutes of Health, Bethesda, Md. and by the Thyroid Clinical Research Fund, No. 5266-5, Massachusetts General Hospital.

\section{REFERENCES}

1. Fraser, F. R. 1976. Results of treatment in exophthalmic goitre. Br. Med. J. 2: 811-812. 
2. Eason, J., and H. L. Wallace. 1932. Toxic goitre: a survey of cases treated during ten years. Edinburgh Med.J. 39: 507-517.

3. Means, J. H. 1937. Graves' disease. In The Thyroid and its Diseases. J. B. Lippincott Co., Philadelphia. lst edition. 306-307.

4. Hershman, J. M., J. R. Givens, C. E. Cassidy, and E. B. Astwood. 1966. Long-term outcome of hyperthyroidism treated with antithyroid drugs. J. Clin. Endocrinol. Metab. 26: 803-807.

5. Douglas, D., and A. T. Kennie. 1952. Thiouracil in toxic goitre. Late results in a personal series. $\mathrm{Br}$. Med. J. 2: 1387-1391.

6. Aspenstrom, G. 1953. Late results with propylthiouracil treatment of hyperthyroidism in a goiter region. Acta Med. Scand. 147: 63-70.

7. Manson, D. I. 1953. Late results of treatment in thyrotoxicosis with thiouracil compounds. Edinburgh Med.J. 60: $321-330$.

8. McCullagh, E. P., and C. E. Cassidy. 1953. Propylthiouracil: 4-6 year follow-up of selected patients with Graves' disease. J. Clin. Endocrinol. Metab. 13: 15071512.

9. Solomon, D. H., J. C. Beck, W. P. Vander Laan, and E. B. Astwood. 1953. Prognosis of hyperthyroidism treated by antithyroid drugs. JAMA (J. Am. Med. Assoc.). 152: 201-205.

10. Goodwin, J. F., H. Steinberg, and A. Wilson. 1954. Longterm therapy of thyrotoxicosis with thiouracil compounds. Br. Med. J. 1: 422-425.

11. Trotter, W. R. 1961. Non-surgical treatment of thyrotoxicosis. Proc. R. Soc. Med. 54: 869-871.

12. Willcox, P. H. 1962. Twelve years' experience of antithyroid treatment. Postgrad. Med. J. 38: 275-280.

13. Reveno, W. S., and H. Rosenbaum. 1964. Observations on the use of antithyroid drugs. Ann. Intern. Med. 60: 982-989.

14. Furth, E. D., M. Rathbun, and J. Posillico. 1969. A modified bioassay for the long-acting thyroid stimulator (LATS). Endocrinology. 85: 592-593.

15. Braverman, L. E., A. G. Vagenakis, C. A. Wang, F. Maloof, and S. H. Ingbar. 1971. Studies on the pathogenesis of iodide myxedema. Trans. Assoc. Am. Phys. 84: 130-138.

16. Braverman, L. E., A. G. Vegenakis, A. E. Foster, and S. H. Ingbar. 1971. Evaluation of a simplified technique for the specific measurement of serum thyroxine concentration. J. Clin. Endocrinol. Metab. 32: 497-502.

17. Bode, H. H., M. Danon, B. D. Weintraub, F. Maloof, and J. D. Crawford. 1973. Partial target organ resistance to thyroid hormone. J. Clin. Invest. 52: 776-782.

18. Doniach, D., and I. M. Roitt. 1963. Clinical application of thyroid auto-antibody tests. In Clinical Immunology, P. G. H. Gill and R. R. A. Coombs, editors. Blackwell Scientific Publications Ltd., Oxford. 611-632.

19. Vallotton, M. B., J. Y. Pretell, and A. P. Forbes. 1967. Distinction between idiopathic primary myxedema and secondary pituitary hypothyroidism by the presence of circulating thyroid antibodies. J. Clin. Endocrinol. Metab. 27: 1-10.
20. Gautvik, K. M., A. H. Tashjian, I. A. Kourides, B. D. Weintraub, C. T. Graeber, F. Maloof, K. Suzuki, and J. E. Zuckerman. 1974. Thyrotropin-releasing hormone is not the sole physiological mediator of prolactin release during suckling. N. Engl.J. Med. 290: 1162-1165.

21. Cuttelod, S., T. Lemarchand-Beraud, P. Magenat, C. Perret, S. Poli, and A. Vannotti. 1974. Effect of age and role of kidneys and liver on thyrotropin turnover in man. Metab. Clin. Exp. 23: 101-113.

22. Savage, R. 1970. Nonparametric Statistics. In Statistics in Endocrinology. J. W. McArthur and T. Colton, editors. The M.I.T. Press, Cambridge, Mass. 1: 215-227.

23. Taunton, O. D., H. G. McDaniel, and J. A. Pittman, Jr. 1965. Standardization of TSH testing. J. Clin. Endocrinol. Metab. 25: 266-277.

24. Berman, D. A. 1961. Fatal coronary occlusion following TSH test. A report of two cases. Minn. Med. 44: 370-373.

25. Baker, S. P., M. Landowne, and G. W. Gaffney. 1960. Electrocardiographic changes following the administration of thyroid stimulating hormone (thyrotropin). Am.J. Cardiol. 6: 905-914.

26. Baker, S. P., G. W. Gaffney, N. W. Shock, and M. Landowne. 1959. Physiological responses of five middleaged and elderly men to repeated administration of thyroid stimulating hormone (thyrotropin; TSH). J. Gerontol. 14: 37-47.

27. Fletcher, R. F., and H. Besford. 1958. A test of thyroid and pituitary function using thyrotropin. Clin. Sci. 17: 113120.

28. Jeffries, W. McK., L. W. Kelly, Jr., R. P. Levy, G. W. Cooper, and R. L. Prouty. 1956. The significance of low thyroid reserve. J. Clin. Endocrinol. Metab. 16: 14381455.

29. Burke, G. 1968. The thyrotropin stimulation test. Ann. Intern. Med. 69: 1127-1139.

30. Palmer, K. T. 1977. A prospective study into thyroid disease in a geriatric unit. N. Z. Med.J. 86: 323-324.

31. Snyder, P. J., and R. D. Utiger. 1972. Response to thyrotropin releasing hormone (TRH) in normal man. J. Clin. Endocrinol. Metab. 34: 380-385.

32. Silverberg, J., and R. Volpe. 1978. Autoimmunity in endocrine disease. In The Year in Endocrinology 1977. S. H. Ingbar, editor. Plenum Publishing Corp., New York. 345-386.

33. Dunn, J. T., and E. M. Chapman. 1964. Rising incidence of hypothyroidism after radioactive-iodine therapy in thyrotoxicosis. N. Engl. J. Med. 271: 1037-1042.

34. Nofal, M. M., W. H. Bierwaltes, and M. E. Patno. 1966. Treatment of hyperthyroidism with sodium iodide $\mathrm{I}^{131}$. A 16-year experience. JAMA (J. Am. Med. Assoc.). 197: $605-610$.

35. van Welsum, M., T. E. W. Feltkamp, M. J. de Vries, R. Doctor, J. van Zijl, and G. Hennemann. 1974. Hypothyroidism after thyroidectomy for Graves' disease: a search for an explanation. Br. Med. J. 4: 755-756.

36. Report of a committee of the Clinical Society of London nominated December 19, 1883, to investigate the subject of myxoedema. 1888. Trans. Clin. Soc. of (Lond.). 21(Suppl): 180 . 